\title{
A Matter of Life and Death: Due Process Protection in Capital Clemency Proceedings
}

In the battle over the constitutionality of the death penalty ${ }^{1}$ during the past twenty years, the trial and appellate stages of the capital punishment process have been scrutinized by the courts ${ }^{2}$ and reworked by the state legislatures. ${ }^{3}$ There has been virtually no attention paid,

1. Supreme Court consideration of the constitutionality of capital punishment procedures is not a recent phenomenon. See, e.g., Powell v. Alabama, 287 U.S. 45, 71 (1932) (capital sentence imposed on defendants lacking adequate representation violates due process); In re Kemmler, 136 U.S. 496, 449 (1890) (death by electrocution not cruel and unusual punishment); Wilkerson v. Utah, 99 U.S. 130, 135 (1878) (death by firing squad not cruel and unusual). However, the argument that the death penalty per se violates the Constitution is of relatively recent vintage. See Goldberg \& Dershowitz, Declaring the Death Penalty Unconstitutional, 83 HARv. L. REv. 1773 (1970) (death penalty violates Eighth Amendment); Gottlieb, Testing the Death Penalty, 34 S. CAL. L. REv. 268, 281 (1961) (same); cf. Rudolf v. Alabama, 375 U.S. 889, 889-91 (1963) (Goldberg, J., dissenting from denial of certiorari) (Court should address constitutionality of death penalty for rape); Brief for the NAACP Legal Defense and Education Fund, Inc., and the National Office for the Rights of the Indigent, as amici curiae at 24-61, Boykin v. Alabama, 395 U.S. 238 (1969) (death penalty cruel and unusual punishment for robbery). See generally M. Meltsner, Cruel and Unusual (1973) (describing legal strategy of death penalty opponents). The first essay in America to call for the abolition of the death penalty was Rush, An Enquiry into the Justice and Policy of Punishing Murder by Death, 4 Am. Museum 78 (1788). See also H. Bedau, The Death Penalty in America 7-13 (1964); P. Mackey, Volces Against Death at i-liii (1976); Filler, Movements to Abolish the Death Penalty in the United States, 284 ANNALs 124 (1952).

2. In Furman v. Georgia, 408 U.S. 238, 289-40 (1972) (per curiam), the Supreme Court held that the death penalty, when imposed without sentencing guidelines, is open to random or discriminatory application, thus violating the Eighth Amendment and the due process clause. In Gregg v. Georgia, 428 U.S. 153 (1976) (plurality opinion), the Court approved a capital statute bifurcating guilt and penalty determinations, providing sentencing guidelines, and mandating state appellate court review for disproportionate or prejudiced sentencing. Accord, Jurek v. Texas, 428 U.S. 262 (1976) (plurality opinion); Proffitt v. Florida, 428 U.S. 242 (1976) (plurality opinion). At the same time, the Court struck down two statutes providing a mandatory death sentence upon conviction of a capital crime. Roberts v. Louisiana, 428 U.S. 325 (1976) (plurality opinion); Woodson y. North Carolina, 428 U.S. 280 (1976) (plurality opinion). The Supreme Court refined its constitutional standards for the death penalty in Beck v. Alabama, 447 U.S. 625, 637$43(1980)$ (unavailability of instruction on Iesser included offense gives jury unconstitutional discretion without guidance), Godfrey v. Georgia, 446 U.S. 420, $428-29$ (1980) (plurality opinion) (vagueness of aggravating circumstance in capital statute allows unconstitutional discretion in application), Lockett v. Ohio, 438 U.S. 586, 604-05 (1978) (sentencer must be free to consider any mitigating circumstance), and Gardner v. Florida, 430 U.S. 349, 355.61 (1977) (plurality opinion) (confidential material not disclosed to defendant cannot be used in determining death penalty).

3. Under the standard of Furman v. Georgia, 408 U.S. 238 (1972), virtually every capital statute then existing was unconstitutional. See Gregg v. Georgia, 428 U.S. 153, 179-80 (1976) (plurality opinion). Within four years, 35 states reenacted the death penalty. Id. Many of these statutes were struck down again under the Court's new standards in 
however, to the clemency ${ }^{4}$ stage of that process. $^{5}$ Now, as prisoners are condemned under newly approved procedures ${ }^{6}$ and as the moratorium on executions ends, ${ }^{7}$ capital clemency has gained importance

Woodson v. North Carolina, 428 U.S. 280 (1976) (plurality opinion), and Roberts v. Louisiana, 428 U.S. 325 (1976) (plurality opinion). At the same time, the Court upheld statutes which then served as a model for constitutionality. Gregg v. Georgia, 428 U.S. 153 (1976) (plurality opinion) (upholding statute requiring bifurcated trial, finding of aggravating circumstance enumerated by statute, open consideration of mitigating circumstances, binding of trial court by jury's recommendation of mercy, and comparative appellate review); Proffitt v. Florida, 428 U.S. 242 (1976) (plurality opinion) (upholding statute requiring bifurcated trial, finding of aggravating circumstance enumerated by statute, consideration of enumerated mitigating circumstances, trial court not bound by jury's sentencing recommendation, and comparative appellate review); Jurek v. Texas, 428 U.S. 262 (1976) (plurality opinion) (upholding statute requiring bifurcated trial, finding of three enumerated aggravating conditions, binding of trial court by jury's recommendation of mercy, and comparative appellate review); see note 2 supra. Since then, new death penalty statutes have been enacted in 24 states, including two states that had abolished the death penalty prior to Furman, bringing the total number of states authorizing capital punishment to 35. National Coalition Against the Death Penalty, Death Row Census (April 20, 1981).

4. Clemency is a broad term that encompasses pardon, reprieve, commutation of sentence, and remission of fines and forfeitures-all functionally similar executive controls over judicially imposed punishment. See Solesbee v. Balkcom, 339 U.S. 9, 1I-12 (1950) (power to reprieve has same source as pardon); note 10 infra (listing constitutional and statutory provisions for clemency). Although clemency is available in noncapital as well as capital cases, historically it is closely wedded to the death penalty and is used comparatively rarely in noncapital cases. S. Stafford, Clemency: Legal Authority, ProCEDURE, AND STRUCTURE at xiii-xiv (1977); see note 11 infra (distinguishing procedures used in capital and noncapital clemency). For the purposes of this Note, discussion is limited to the process of commutation of a death sentence to a term of imprisonment.

5. The Supreme Court has only briefly considered clemency since enunciating the procedural standard in Furman v. Georgia, 408 U.S. 238 (1972). In the course of rejecting petitioner's Eighth and Fourteenth Amendment arguments, the Court declined to hold that the discretion inherent in clemency is unconstitutionally arbitrary. Gregg v. Georgia, 428 U.S. 159, 199 (1976) (plurality opinion). The Gregg decision thus left unchanged the uncertain constitutional status of state clemency provisions not surrounded by due process protections. Lower federal and state courts have rejected attacks on clemency procedures. See Spinkellink v. Wainwright, 578 F.2d 582, 617-19 (5th Cir. 1978), cert. denied, 440 U.S. 976 (1979) (due process not triggered at clemency stage); Sullivan v. Askew, 348 So. 2d 312, 314 (Fla.), cert. denied, 434 U.S. 878 (1977) (clemency procedures wholly within executive discretion); id. at 317 (England, J., concurring) (state's clemency procedures constitutional under due process standard).

6. See note 3 supra. Seven hundred eighty-four men and eight women are currently under sentence of death in 31 states. National Coalition Against the Death Penalty, supra note 3.

7. The annual rate of recorded executions in this country slowed from a high of 199 in 1935 to a handful each year in the mid-1960s. W. BOWERS, Executions IN AMERIGA 2223 (1974).

The reluctance of courts and executives to schedule executions, and the growing burden of death penalty litigation, resulted in a de facto moratorium on executions from 1967 until Gary Gilmore was executed in Utah in 1977. In 1979, two other prisoners, John Spenkelink in Florida and Jesse Bishop in Nevada, were put to death. All three men had been denied clemency. Death Warrant of John Spenkelink (May 18, 1979) (signed by Florida Governor R. Graham) (on file with Yale Law Journal); Nevada Board of Pardons, Transcript of Proceedings, Jesse Bishop at 80 (Aug. 25, 1979) (on file with Yale Law Journal) [hereinafter cited as Bishop Hearing]; Utah Board of Pardons, Transcript of 


\section{Clemency}

as the last chance of relief for death row inmates who are exhausting their appeals. ${ }^{8}$

Although clemency is critical to the process of determining punishment in capital cases, executive authorities today exercise their power virtually free from procedural control by the courts. Such uncontrolled discretion permits practices that detract from the value of clemency as the state's final opportunity to assess the appropriateness of a death sentence. This Note argues that procedural protections should be extended to the clemency stage of the capital punishment process for clemency to fulfill its expected role in determining punishment and to satisfy the high procedural standards demanded by the Supreme Court when life is at stake. The Note recommends procedural safeguards that would enhance the amount and accuracy of information available to the clemency authority, without infringing on the substantive discretion inherent in the clemency power.

\section{The Capital Clemency Process}

Although the reasons for granting capital clemency have varied historically, ${ }^{9}$ the executive power to spare prisoners from the death penalty is deeply rooted in Anglo-American criminal law. As one link in the chain of decisions by which the state selects offenders for capital punishment, clemency is functionally integrated with the earlier, judicial stages of the process. Yet the clemency decision also involves the consideration of factors that are not cognizable in the ju-

Proceedings, In re Gary Mark Gilmore at 66-67 (Nov. 30, 1976) (on file with Yale Law Journal) [hereinafter cited as Gilmore Hearing].

In 1981, Steven Judy was executed in Indiana. A third-party application for clemency was refused for reasons of standing. Statement of Indiana Parole Board and Clemency Commission (Mar. 6, 1981) (on file with Yale Law Journal).

8. Since 1976, capital clemency applications have been made in six states-Florida, Georgia, Indiana, Montana, Nevada, and Utah. Clemency has been denied in eighteen cases, resulting in three executions, see note 7 supra; granted in five cases, Interview with Silas Moore, Hearing Examiner, Georgia State Board of Pardons and Paroles, in Atlanta, Ga. (Mar. 26, 1981) (notes on file with Yale Law Journal); Interview with Betty Steffens, Deputy General Counsel to the Governor of Florida, in Tallahassee, Fla. (Mar. 26, 1981) (notes on file with Yale Law Journal); refused for standing reasons in one case resulting in an execution, see note 7 stpra; refused as premature in one case, see note 12 infra; and determinations are still pending in ten cases, Interview with Betty Steffens, supra.

9. Compate 1 L. Radzinowicz, A History of English Criminal Law and Its AdminISTRATION FROM 1750, at 114-16 (1948) (youth, first offense, provocation, and nonviolent nature of crime among historical factors in clemency) and $F$. BRESLER, REPRIEvE 20, 27, 54-55 (1965) (same) with Note, Executive Clemency in Capital Cases, 39 N.Y.U. L. REv. $136,159-78$ (1964) (disparity in sentencing, mental condition, political pressure, and views on capital punishment among contemporary reasons for clemency) and Johnson, Selective Factors in Capital Punishment, 86 Socral Forces 165, 167 (1957) (same). 
dicial process. Proper exercise of the clemency power requires that the decisionmaker have full and accurate information about the offender, the offense, and the needs of society, in order to determine whether to spare the condemned prisoner.

\section{A. The Political Nature of the Clemency Power}

Most state constitutions ${ }^{10}$ grant executive authorities the power to spare prisoners from a lawful sentence of death. ${ }^{11}$ Though it is rare for state procedure to require a prisoner to await final denial of judicial relief before seeking clemency, ${ }^{12}$ the clemency application ordinarily presupposes that no judicial remedy, based entirely on the jurisdiction's positive criminal law, is available. Widely recognized reasons for granting executive clemency include the amelioration of

10. All 36 states that authorize the death penalty also have constitutional or statutory provisions for capital clemency. ALA. CoNst. amend. XXXVIII; ARIZ. ConsT. art. V, § 5; Ark. Const. art. VI, § 18; Cat. Const. art. V, § 8; Colo. Const. art. IV, § 7; ConN. Gen. Stat. § 18-26 (1981); Del. Const. art. VII, § 1; FrA. Const. art. IV, § 8(a); GA. Const. $\S 2-2001$; IDAho Const. art. IV, § 7; ILl. Const. art. V, § 12; IND. Const. art. V, § 17; Kx. Const. § 77; LA. Const. art. IV, § 5(E); MD. Const. art. II, § 20; Miss. Const. art. V, § 124; Mo. Const. art. IV, § 7; Mont. Const. art. VI, § 12; N'EB. Const. art. IV, § 13; Nev. Const. art. V, $\S 14 ;$ N.H. Const. pt. 2, art. 52; N.M. Const. art. V, § 6; N.Y. Const. art. IV, § 4; N.C. Const. art. III, § 5(6); OHio Const. art. III, § Il; OKLA. Const. art. VI, § 10; PA. Const. art. IV, § 9(a); S.C. Const. art. IV, § 14; S.D. Const. art. IV, § 3; Tenn. Const. art. III, § 6; TeX. Const. art. IV, § 11; UtAh Const. art. VII, § 12; VA. Const. art. V, § 12; Vr. Const. ch. II, § 20; WASh. Const. art. III, § 9; WYo. Const. art. IV, § 5. See also U.S. CoNsr. art. II, $\$ 2$ (President "shall have Power to grant Reprieves and Pardons for Offenses against the United States, except in Cases of Impeachment.")

In most states, the power to commute a death sentence is one of a set of other functionally similar executive powers such as pardon, reprieve, and restoration of rights. See, e.g., Colo. Const. art. IV, § 7; GA. Const. § 2-2001; Nev. Const. art. V, § 14.

11. Some jurisdictions distinguish clemency in capital cases from clemency in noncapital cases by vesting the power differently or by specifying different procedures. See, e.g., AlA. Const. amend. XXXVIII (governor has commutation power in capital cases; legislature has power in noncapital cases); ARuz. REv. STAT. ANN. § 31-445 (West 1976) (requirement of publication of reasons for grant of clemency limited to capital cases); Fla. R. Exec. Clemency 7 (special rules for capital cases). See generally S. Staffokd, supra note 4, at 8-90 (summarizing state clemency provisions).

12. See Note, supra note 9, at 153 (purpose of clemency best served when judicial process complete). In Florida, clemency consideration is triggered by automatic notification of the completion of state appellate court review, thus preceding state and federal habeas remedies. FrA. R. Exec. Cuemency 7(A). As a result, the focus of the clemency process in Florida has been shifted to consideration of judicial, rather than the traditional extra-judicial, factors. Interview with Richard Shapiro, Dixector, Southern Prisoners' Defense Committec, in New Orleans, La. (Oct. 10, 1980) (because of timing of Florida clemency application, focus is on validity of death sentence, rather than on its appropriateness, contrary to classic clemency model) (notes on file with Yale Law Journal) [hereinafter cited as Shapiro Interview].

Timing in other states is discretionary. In Montana, the governor denied as premature the clemency application of a prisoner, sentenced under a mandatory statute, who had delayed his appeal. Interview with Michael McCarter, Assistant Attorney General, in Helena, Mont. (June 25, 1980) (notes on file with Yale Law Journal). Clemency applications were considered in Utah and Nevada upon withdrawal of all appeals by petitioners. 
unduly harsh sentences, ${ }^{13}$ the exercise of compassion on account of physical illness or other hardship, ${ }^{14}$ and the healing of political wounds. ${ }^{15}$

The essential contention of a clemency petition is that the public interest would be better served by sparing the life of the condemned than by taking it. ${ }^{10} \mathrm{~A}$ clemency decision therefore is political in nature, in that it addresses factors that courts are unable to consider in setting or reviewing sentences. ${ }^{17}$ Although there are judicially en-

13. See note 9 supra; note 16 infra.

14. See OHo Rev. Code ANN. $\$ 2967.05$ (Page 1975) (governor may release dying prisoner as if on parole).

15. See, e.g., Pres. Proc. 4483, 3 C.F.R. 4 (1978) (President Carter's amnesty for draft cvaders); Pres. Proc. 4311, 3A C.F.R. 66 (1974) (President Ford's pardon of former-president Nixon); Pres. Proc. 37, 13 Stat. 758 (1865) (President Andrew Johnson's amnesty for former secessionists).

16. The Supreme Court, in Biddle v. Perovich, 274 U.S. 480 (1927), stated:

A pardon in our days is not a private act of grace from an individual happening to possess power. It is a part of the Constitutional scheme. When granted it is the determination of the ultimate authority that the public welfare will be better served by inflicting less than what the judgment fixed.

Id. at 486. See also DiSalle, Comments on Capital Punishment and Clemency, 25 OHI ST. L.J. 71, 77 (1964) (remarks of Averill Harriman, Governor of New York) (clemency needed to weigh factors that judge and jury could not take into consideration and needed when law is inflexible); id. at 77 (remarks of G.E. Chamberlain, Governor of Oregon) (duty of executive branch to equalize uneven administration of justice); Weihofen, Pardon: An Extraordinary Remedy, 12 Rocky MTN. L. REv. 112, 113 (1940) (clemency needed when letter of law would violate community sense of justice); Interview with Donnie $A$. Lee, Exccutive Officer, Georgia State Board of Pardons and Paroles, in Atlanta, Ga. (Oct. 10, 1980) (notes on file with Yale Law Journal) ("The work of the board is the compassionate part of the criminal justice system.") [hereinafter cited as Lee Interview].

The public interest, inherent in the clemency consideration, may be asserted by third parties when the condemned prisoner chooses not to apply for clemency. See Gilmore Hearing, supra note 7 , at 8,9 (witnesses testifying in favor of clemency without prisoner's consent); Bishop Hearing, supra note 7, at 56-60 (same). But see Statement of Indiana Parole and Clemency Board, supra note 7 (refusing third-party clemency application). In this regard clemency is again distinguished from strictly judicial proceedings, in which only the interests of the offender, and the state as represented by the prosecutor, are recognized. See Evans v. Bennett, 440 U.S. 1301 (1979) (Rehnquist, Circuit Justice) (rejecting application of prisoner's mother to appeal in his behalf as next friend); Gilmore v. Utah, 429 U.S. 1012 (1976) (same).

17. Although some factors once considered only by the clemency authority are now weighed by the sentencer and by the appellate courts in capital cases, see Lockett v. Ohio, 438 U.S. 586, 604-07 (1978), clemency remains an essential opportunity for the state to consider information excluded from previous stages of the capital punishment process, and to reconsider information previously applied to the case only in a judicial setting. Thus, the clemency authority may act out of opposition to capital punishment, Eacret $v$. Holmes, 333 P.2d 74I, 743 (Or. 1958), even though jurors with such scruples may be barred from serving in capital cases, Witherspoon v. Illinois, 391 U.S. 510, 516-18 (1968), and appellate courts may not act upon such personal feelings, Furman v. Georgia, 408 U.S. 238, 375 (1972) (Burger, C.J., dissenting); id. at 410-11 (Blackmun, J., dissenting). The clemency authority is also free to weigh purely political considerations. S. STAFForD, supra note 4, at $\mathrm{Xv}$ (pardons may have political aspect); see Note, supra note 9 , at 172-75 (politics can affect clemency decision). Other information, such as a prisoner's subsequent progress toward rehabilitation, or loss of sanity, is unavailable earlier in the punishment- 
forceable jurisdictional limitations on the clemency power, ${ }^{18}$ a clem-
ency decision itself is, in effect, judicially unreviewable. ${ }^{10}$ The ex-

determination process. Information not presented earlier because of inadequate counsel, strategic considerations, or the unavailability of witnesses may also be heard. Interview with John C. Boger, Staff Attorney, NAACP Legal Defense and Education Fund, Inc., in New York, N.Y. (July 2, 1980) (notes on file with Yale Law Journal); see Lee Interview, supra note 16 (clemency board in Georgia reviews new information).

Information considered earlier may be seen in a new light because of differences in the screening mechanisms. The clemency authority determines for itself both the factors it will weigh and their relative importance without the direction of statutory guidelines. See Note, supra note 9, at 177-78. The clemency authority is closer in time to the execution of sentence and more remote from the offense, and consequently may shift its focus from the victim to the offender, thereby giving less weight to retributive notions of punishment. Interview with Patsy Morris, Georgia Civil Liberties Union, in Atlanta, Ga. (Oct. 10, 1980) (notes on file with Yale Law Journal). The individual responsibility, characteristic of most state clemency schemes, differs from the collective responsibility of sentencers and courts. See note $\mathbf{3 8}$ infra (sentencers and courts rely on clemency as safeguard). Finally, in addition to these institutional distinctions, the fact that different people may make different decisions based on the same information provides the safeguard of an additional level of approval-and opportunity for disapproval-before a death sentence may be carried out. Rockefeller, Executive Clemency and the Death Penalty, 21 Cath. L. Rev. 94, 95 (1971).

18. Civil penalties cannot be commuted, nor can crimes against other jurisdictions, including the violation of municipal ordinances within the state. 3 U.S. DEP'T OF JUSTICE, Survey of Release Procedures 134-41 (1939) [hereinafter cited as Justice Survey]; cf. F. Mattund, The Constitutional History of England 479 (1908) (no royal pardon power over civil justice). Substantive limitations are also imposed by the federal and most state constitutions, with treason and impeachment commonly removed from the executive power. Justice SuRveY, supra, at 133; S. STAFrorn, supra note 4, at 2, 3; cf. Schick v. Reed, 419 U.S. 256, 267 (1974) (limitations on clemency power must be found in Constitution).

19. Spinkellink v. Wainwright, 578 F.2d 582, 618 (5th Cir. 1978), cert. denied, 440 U.S. 976 (1979) (clemency decision discretionary and "not the business of judges"); Sullivan v. Askew, 348 So. 2d 312, 315 (Fla.), cert. denied, 434 U.S. 878 (1977) (legislature and judiciary prohibited from encroaching on executive clemency power); Ex parte Crump, 135 P. 428, 431 (Okla. Crim. 1913) (judicial review of clemency would violate separation of powers); Eacret v. Holmes, 383 P.2d 74I, 744 (Or. 1958) (courts cannot review reasons for clemency); Justice SURveY, supra note 18, at 128-32 (exercise of executive clemency cannot be reviewed by court); $i d$. at 113 (legislature cannot restrict clemency power).

Although courts have held that the substance of a clemency decision is not subject to judicial review, limitations on the clemency power may be subject to enforcement by the courts. See Schick v. Reed, 419 U.S. 256, 267 (1974) (limitations on clemency power must be found in Constitution); McGee v. Arizona State Bd. of Pardons \& Paroles, 376 P.2d 779 (Ariz. 1962) (actions of clemency authority reviewable for compliance with state law and due process); Sullivan v, Askew, 348 So. 2d 312, 317 (Fla.), cert. denied, 494 U.S. 878 (1977) (England, J,, concurring) (capital clemency procedures reviewable for minimal due process standards); Justice SuRveY, supra note 18, at 130-31 (pardon reviewable for compliance with state law).

Moreover, if constitutional norms apply to clemency as they do to other governmental actions, a clemency decision could not be based on constitutionally impermissible reasons. See Schick v. Reed, 419 U.S. 256, 267 (1974) (conditions imposed with clemency must be constitutionally unobjectionable). A decision based on race, for example, might be found to violate the equal protection clause; one based on the flip of a coin might violate the Eighth Amendment's ban on arbitrariness as enunciated in Furman v. Georgia, 408 U.S. 238 (1972). This issue has not been directly addressed by the courts. See Note, supra note 9, at 181-82 (race); Gregg v. Georgia, 428 U.S. 153, 199-200 (1976) (plurality opinion) 


\section{Glemency}

ecutive authority's general accountability to the electorate ${ }^{20}$ provides the principal check on clemency decisions.

\section{B. The Place of Capital Clemency Within the Capital Punishment System}

The Anglo-American Tradition. Until recent times, most felonies in Anglo-American jurisdictions ${ }^{21}$ were punishable, not by imprisonment, but by death. ${ }^{22}$ In early criminal proceedings, it was difficult and frequently impossible to assert mitigating facts and to introduce special defenses. ${ }^{23}$ In England, before the nineteenth century, the harshness of capital statutes was mitigated to some extent by the lenient interpretation of trial judges and by jury nullification-by finding defendants innocent despite the facts. ${ }^{24}$ For individuals who were convicted of capital offenses, clemency provided the principal opportunity for relief.25

Grown law officers and ministers who controlled royal clemency extended mercy to individuals for whom capital punishment seemed inappropriate, even though they had been convicted and sentenced

(arbitrariness). See also Wolfgang, Kelly, \& Nolde, Comparison of the Executed and the Commuted Among Admissions to Death Row, 53 J. CRM. L.C. \& P.S. 301, 305-11 (1962) (offenders who are black, foreign-born, or represented by court-appointed counsel less likely to receive clemency).

20. See Ex parte Crump, 135 P. 428, 431 (Okla. Crim. 1913) (flagrant abuse of clemency power may warrant impeachment); JUSTICE SURVEY, supra note 18, at 148-53 (impeachment remedy for abuse of pardon power).

21. Chief Justice Marshall attributed the institutional framework of clemency to its inheritance from British tradition. United States v. Wilson, 32 U.S. (7 Pet.) 150, 160 (1833).

22. See L. Radzinowicz, supra note 9 , at $\mathbf{3 1 - 3 3}$ (satisfactory secondary punishments lacking).

The number of statutes carrying a penalty of death increased dramatically in eighteenthcentury England, and peaked at well over 200. Id. at 1-5. The earliest record of colonial capital statutes, from the Massachusetts Bay Colony dated 1636, shows 13 capital offenses, each justified by a citation to the Old Testament. Haskins, "The Capitall Lawes of New England", HARv. L.S. Bull., Feb. 1956, at 10-11. Laws adopted by Quaker colonists in South Jersey and Pennsylvania were far milder. But as late as 1837, North Carolina listed some 25 capital offenses, many slavery-related. H. BEDAU, supra note 1, at 6-7.

23. Claims of accident, insanity, and self-defense were incorporated into English jurisprudence through clemency. F. BRESLER, supra note 9, at 27; Grupp, Some Historical As. pects of the Pardon in England, 7 AM. J. LeGal Hist. 51, 60 (1963).

24. L. Radzinowicz, supra note 9, at 91-96; see Woodson v. North Carolina, 428 U.S. 280, 293 (1976) (plurality opinion) (American tradition of jury nullification); H. KALVEN \& H. ZeISEL, THE AMERICAN JURY 310-12 (1971) (comparing modern American and early English jury nullification); D. Rothman, The Discovery of the Asylum 60 (1971) (nullification by colonial juries); Note, Daring the Courts: Trial and Bargaining Consequences of Minimum Penalties, 90 YALE L.J. 597, 600-01 (1981) (defining jury nullification and citing early English tradition).

25. S. Milsom, Historical Foundations of the Common Law 367 (1969) (pardon served some functions later served by appeals); L. RADzinowicz, supra note 9, at 116 (clemency necessary to individualized punishment). 
in accordance with contemporary judicial standards. ${ }^{26}$ Grants of clemency were not rare; royal pardons appear to have been granted in substantial proportion to the number of offenses punishable by death. ${ }^{27}$ In British North America, clemency was exercised by colonial governors. ${ }^{28}$ After independence, following a brief reaction against executive authority, the new American states returned the clemency power to the governor's office. ${ }^{29}$

Within the American tradition, clemency was widely understood to be an integral part of the system by which the state selected offenders for death; ${ }^{30}$ no death sentence was truly irrevocable until the condemned prisoner was actually executed..$^{31}$ As the implementation of penological reforms accelerated, ${ }^{32}$ the clemency power attained significance in the overall punishment-determination process as the opportunity for executive revision of judicial punishments. As Chief Justice Marshall observed in 1833, such an executive power was "a constituent part of the judicial system." 33

The Contemporary Clemency System. Although trial and appellate procedures have changed dramatically since the nineteenth century, clemency retains its traditional importance in the process of determining punishment. It is as routine for a condemned prisoner to seek clemency today as it is for him $^{34}$ to seek appellate review. ${ }^{\text {s5 }}$

26. Among the factors to emerge as reasons io extend mercy were youth, Grupp, supra note 23, at 61; old age, F. BREsLER, supra note 9, at 54; pregnancy, id.; and the nonviolent nature of the crime, L. RADziNowicz, supra note 9, at 114-16.

27. In the last decade of the eighteenth century, more than four-fifths of all convicted capital offenders had their sentences remitted. $\mathbf{L}$. RADziNowicz, supra note 9 , at 120 n.48.

28. Duker, The President's Power to Pardon: A Constitutional History, 18 WM. \& MARY L. REv. 475, 497-501 (1977).

29. JUSTIGE SURVEY, supra note 18, at 89-90.

30. See United States v. Wilson, 32 U.S. (7 Pet.) 150, 161 (1833) (pardon is constituent part of judicial system).

31. Cf. NEB. REv. Stat. $\$ \S 83-1,132$ (1976) (death sentence may not be carried out until ruling on clemency application); F. BRESLER, supra note 9, at $\mathbf{3 7 - 3 8}$ (prisoner hanged but not yet dead cut down from scaffold when pardon received); Note, supra note 9, at 157 (denial of clemency in New York not announced in case of change).

32. The notion that the task of sentencing is to select particular offenders for particular punishments gained acceptance during the late nineteenth century. See D. RorHMAN, supra note 24, at 57-58 (describing penal reform movement during this period).

33. United States v. Wilson, 32 U.S. (7 Pet.) 150, 161 (1833) (nineteenth-century view of clemency).

34. For consistency, masculine pronouns are used throughout this Note because $99 \%$ of condemned prisoners are male. National Coalition Against the Death Penalty, supra note 3 .

35. Interview with John C. Boger, Staff Attorney, NAACP Legal Defense and Education Fund, Inc., in New York, N.Y. (Oct. 14, 1980) (notes on file with Yale Law Journal). In contrast, a condemned prisoner not seeking clemency is considered newsworthy. See Death Wish, NewsweEk, Nov. 29, 1976, at 26-33 (Gary Gilmore cover story). 
Attorneys representing death-row inmates believe it is important to begin planning for clemency petitions long before the exhaustion of judicial remedies, and they attempt to integrate that planning into their overall defense strategy. ${ }^{36}$

The other participants in the criminal justice system also retain the traditional expectation that the clemency petition plays a role in the state's selection of offenders for the death penalty. Legislators who draft and revise criminal codes continue to rely upon executive clemency as a politically sensitive mechanism to prevent the imposition of the death penalty in particular cases. ${ }^{37} \mathrm{~A}$ similar expectation affects judges and juries in capital cases. ${ }^{38}$ Whether conceived as a power to correct judicial failures that courts themselves cannot overcome ${ }^{30}$ or as a power to introduce a nonjudicial sense of the public interest into the process of determining punishment, ${ }^{40}$ clemency is functionally integrated with the rest of the capital punishment system. If clemency is sought, the state cannot take an offender's life until the ex-

36. Southern Prisoners' Defense Committee, A Handbook for Attorneys Representing Prisoners Before the Florida Clemency Board 8 (1980) (on file with Yale Law Journal); Interview with John C. Boger, supra note $\mathbf{3 5}$ (preparation for clemency should begin as soon as attorney takes case); Interview with David E. Kendall, Attorney for John Spenkelink, in Washington, D.C. (June 30, 1980) (notes on file with Yale Law Journal).

37. Interview with Henry Schwarzschild, Director, ACLU Capital Punishment Project, in New York, N.Y. (May 7, 1980) (legislators cite opportunity for clemency among safeguards against error justifying their vote in favor of capital punishment) (notes on file with Yale Law Journal).

38. See In re Anderson, 69 Cal. 2d 613, 623, 447 P.2d 117, 124, 73 Cal. Rptr. 21, 28 (1968) (clemency is safeguard against arbitrary jury action); People v. Broncado, 188 N.Y. 150, 151, 80 N.E. 935, 936 (1907) (additional mitigating circumstances should be submitted to governor for consideration at clemency); W. Huie, The Execution of Private SLovik 169, 173 (1970) (court martial and reviewing authorities expected President to grant clemency); B. Wolfe, Pileup on Destr Row 37, 38 (1973) (judge, denying motion for stay of execution, attributed opportunity to raise humanitarian concerns to clemency); id. at 177, 178 ("In making your determination as to the penalty to be imposed, you may . . . consider as a possible consequence that the law of this state provides that a defendant sentenced ... to death ... may be pardoned or have his sentence reduced by the Governor . . . .") (quoting California jury instructions now prohibited); Leavy, Mamie Lee Ward on Death Row, Ms., Nov. 1975, at 70, 106 (interviews with jurors revealed belief that death sentence would lead to longer imprisonment rather than execution); Mailer, Until Dead, Parade, Feb. 8, 1981, at 8 (Gary Gilmore's prosecutor believed death sentence would be commuted).

39. See Fay v. Noia, 372 U.S. 391, 476 (1963) (Harlan, J., dissenting) (appellee's remedy lies with executive clemency rather than judicial power).

40. The Court in Ex parte Grossman, 267 U.S. 87 (1925), stated:

Executive clemency exists to afford relief from undue harshness or evident mistake in the operation or enforcement of the criminal law. The administration of justice by the courts is not necessarily always wise or certainly considerate of circumstances which may properly mitigate guilt. To afford a remedy, it has always been thought essential in popular governments, as well as in monarchies, to vest in some other authority than the courts power to ameliorate or avoid particular criminal judgments. It is a check entrusted to the executive for special cases.

Id. at 120-21. 
ecutive authority has determined that no reason exists to commute the death sentence.

\section{Systemic Features}

Two systemic features of clemency reflect its anomalous character as the final, essentially political inquiry into the appropriateness of a lawful death sentence at the end of the judicial process. The first feature is its insulation from judicial review. The political character of clemency makes freedom from judicial control important to the performance of the executive branch's function. ${ }^{41}$ It is precisely because society remains uneasy with the judicial process of criminal law enforcement that it has placed outside the courts the power to review and adjust sentences. ${ }^{42}$

The legislature, the courts, and the public expect, however, that a clemency authority will gather and consider all the information that could affect its decision. ${ }^{43}$ Consideration of a clemency application is the state's last opportunity to gather information about the prisoner and his conduct, and to formulate an official response. ${ }^{4 t}$ The prisoner, ${ }^{45}$ his family, ${ }^{46}$ prison officials, ${ }^{47}$ judges, ${ }^{48}$ state prosecutorial officials, ${ }^{49}$ and other members of the community ${ }^{50}$ at times

41. See p. 893 supra; note 21 supra.

42. See note 40 supra.

43. The informational role to be played by clemency is not a new expectation. Lord Eldon described a monthly session on clemency at the Old Bailey:

I was exceedingly shocked ... the first time I attended to hear the Recorder's report, at the careless manner in which, as it appeared to me, it was conducted. We were called upon to decide on sentences, affecting no less than the lives of men, and yet there was nothing laid before us, to enable us to judge whether there had or had not been any extenuating circumstances ....

L. Radzinowicz, supra note 9, at 116 .

44. Rockefeller, supra note 17, at 95 ("[E]xecutive clemency provides the state with a final deliberative opportunity to reassess the moral and legal propriety of the awful penalty which it intends to inflict.")

45. See, e.g., R. MeEropol \& M. Meeropor, We Are Your Sons 224-26 (1975) (letter from Ethel Rosenberg to President Eisenhower asking for clemency); B. WoLfE, supra note 38, at 49, 50 (letter from Aaron Mitchell to Governor Pat Brown asking for clemency);

Lee Interview, supra note 16 (clemency investigation begins with interview of inmate).

46. See, e.g., R. Meeropol \& M. MeEropol, supra note 45, at 223 (letter from son of Julius and Ethel Rosenberg to President Eisenhower, asking for clemency for parents); B. WoLfE, supra note 38 , at 32 (mother of condemned weeping at clemency hearing); Lee Interview, supra note 16 (state interviews parents of clemency applicant).

47. See F. Bresler, supra note 9, at 97, 101 (information from prison guards used by British clemency authority); Note, supra note 9, at 168 (guards testified as to rehabilitation of clemency applicant).

48. See L. Radzinowicz, supra note 9, at 111-13 (judge's recommendation is important); Note, supra note 9, at 170-72 (opinion of trial and appellate judges taken into account); Lee Interview, supra note 16 (same).

49. See Note, supra note 9, at 171-72 (recommendation of prosecutor weighed by clemency authority); note 58 infra (prosecutors involved in clemency decisions).

50. See 1 H. Twiss, Life of Lord Chancerlor Eldon 398.99 (London 1844), cited in 
even representatives of the victim ${ }^{51}$-traditionally have provided information to the clemency authority.

\section{Executive Performance in Capital Clemency Decisionmaking}

The correctness of a decision to grant or deny clemency is, at present, substantively unreviewable by the courts. Moreover, public disapproval of clemency decisions has only muffled effect at the polls. It is therefore difficult to assess the quality of executive decisionmaking in capital clemency cases. Yet, in light of the expected functions of clemency, it is possible to determine whether current clemency procedures ensure that clemency performs its role in the process of determining punishment.

\section{A. Current Practices}

Capital clemency procedures vary among jurisdictions. Most states and the federal government vest the clemency power solely in the chief executive, although some give authority to a clemency board or to the governor acting upon the recommendation of such a board. ${ }^{52}$ The executive officers possessing clemency authority generally delegate the investigation of clemency applications to their staff or to a government agency. ${ }^{53}$ Medical and psychiatric information, as well as nonexpert information, may be considered..$^{54}$ The applicant may provide information to the clemency authority through written sub-

L. Ranzinowicz, supra note 9 , at $116 \mathrm{n} .35$ (clemency granted when recommended by cabinet official from locale of offense); Johnson, supra note 9, at 167 (community opinion is factor in clemency); Southern Prisoners' Defense Committee, supra note 36, at 19 (mobilizing support of community in which crime committed may be helpful).

51. See L. Radzinowicz, supra note 9, at 115; Bishop Hearing, supra note 7, at 71; Lee Interview, supra note 16 (Georgia Board of Pardons and Paroles interviews victim's family).

52. The governor has sole authority in 31 states; clemency boards have sole power in 10 states; the governor has power upon the recommendation of a board in 7 states. S. Stafford, supra note 4, at 1. Two states have different systems. California vests the power in the governor except in the case of twice-convicted felons, when the recommendation of the majority of the state supreme court is required. CAL. Const. art. V, $\S$ 8. The Rhode Island governor can grant clemency only with the consent of the state senate. R.I. CoNST. amend. II.

53. See, e.g., NEv. REv. STAт. $\$ 213.040$ (prosecuting attorney required to prepare factual statement for clemency board); N.Y. ExEc. LAw \& 259(c)(8) (McKinney Supp. 19721980) (governor may request investigation by Board of Parole); UTAF CoDE ANN. § 7762-3(a) (hearing is the only required information-gathering opportunity for clemency board); FlA. R. Exec. Clemency 7 (clemency authority may request investigation by Parole and Probation Commission); Lee Interview, supra note 18 (Georgia Board of Pardons and Paroles has own investigatory staff).

54. See Shapiro Interview, supra note 12 (psychiatric testimony important in clemency application); Interview with Patsy Morris, supra note 17 (medical and psychiatric testimony important). 
missions, ${ }^{55}$ witness testimony, ${ }^{56}$ and oral presentations. ${ }^{57}$ The prosecutor $^{58}$ and others who oppose clemency ${ }^{50}$ may also provide information. When such information, particularly expert information, generates uncertainties and disputes about the applicant's case, ${ }^{60}$ the clemency authorities must resolve them.

\section{B. Procedural Inadequacies of Current Practices}

The absence in many states of procedural guarantees that assure the clemency applicant fair access to the decisionmaker and an opportunity to present his case jeopardize the completeness ${ }^{61}$ and the

55. Affidavits are particularly important in states in which the direct testimony of witnesses is not allowed. Shapiro Interview, supra note 12; see FuA. R. EXEC. ClemencX 7(A), (D) (oral presentation at hearing limited to attorneys).

56. Witness testimony is sometimes allowed, see, e.g., Bishop Hearing, supra note 7, but is prohibited in Florida, see FlA. R. ExEc. Clemencr 7(A), (D); Shapiro Interview, supra note 12 .

57. Florida limits oral presentation by the attorney for the applicant and the prosecuting attorney to $\mathbf{3 0}$ minutes each. FrA. R. Exec. Clemency 7(D).

58. Twenty-seven states have a statutory requirement that the prosecutor be notified of applications for clemency. S. Stafford, supra note 4, at 2 n.7; see, e.g., ARIz. REv. STAT. \$ $31-442$ (West 1976); Cal. Penal Code $\S 4803$ (West 1981); LA. Rev. Stat. AnN. \$ 15:572.4(B) (West 1981).

In clemency hearings held in Florida and Georgia following the Supreme Court's decision in Grezg v. Georgia, 428 U.S. 153 (1976), prosecuting attorneys argued against clemency by reiterating the aggravating circumstances underlying the original death sentence. E.g., Transcript of Clemency Hearing, Willie Darden (Fla. May 8, 1979) (on file with Yale Law Journal); Summary of Commutation Proceedings, Georgia v. Dix (May 18, 1978) (on file with Yale Law Journal). In one case, the prosecutor passed out color photographs of the murder victim to the clemency board. Transcript of Clemency Hearing at 19, James Dupree Henry (Fla. May 17, 1979) (on file with Yale Law Journal). In Florida and Nevada, the state's chief prosecutorial officer, the attorney general, is a member of the clemency board. See FLA. CoNsr. art. IV, \$ 8(2) (approval of three cabinet members required for clemency); id. art. IV, $\S 4(a)$, (c) (attorney general is member of cabinet and chief state legal officer); NEv. Consr. art. V, $\S 14$ (attorney general is member of clemency board).

59. Many states require publication of notice of a clemency hearing in the county of conviction. E.g., Miss. CoNst. art. V, § 124; ARIZ. Rev. STAT. § 31-442 (West 1976). Investigation by the clemency authority may also reveal opposition to a clemency application. See Lee Interview, supra note 16 (some interviewed oppose grant of clemency).

60. Interview with John C. Boger, supra note 35 (expert witnesses may provide contradictory testimony).

61. When the state has responsibility for gathering information, institutional factors may prevent some information from being obtained. The applicant may not trust the state's investigator and may decline to reveal information that might otherwise be helpful to him. See, e.g., Lee Interview, supra note 16 (prisoner would not provide access to certain data after evaluating interviewer). Witnesses for the applicant may be intimidated by the state interviewer. Shapiro Interview, supra note 12 (poor black witnesses may be intimidated by state interviewer, usually white parole officer). Moreover, the state investigator's role is distinct from that of an advocate for the applicant. Lee Interview, 
reliability of the information that the clemency authority may consider. Without an attorney, ${ }^{62}$ without knowledge of all the information held against him, ${ }^{63}$ without an opportunity to appear personally before the clemency authority, ${ }^{64}$ without adequate notice ${ }^{65}$ of a hearing, or without any hearing at all, ${ }^{66}$ the condemned prisoner cannot correct or rebut information adverse to his application. The lack of procedural safeguards ${ }^{27}$ thus converts the clemency proceeding into an opportunity for state prosecutorial officers to exert, possibly without check, all their powers of persuasion against the condemned prisoner. The states' failure to provide procedures for full consideration of a clemency application may cause the decision to reflect an inaccurate view of the case. The procedural inadequacies thus undercut the broad societal expectation that the clemency authority, as the state's last participant in the capital punishment process, will act deliberatively and with care.

supra note 16 (investigator tries to remain objective). Lack of resources-time and money -may also hamper the applicant's attorney in making a complete investigation. Interview with David E. Kendall, supra note 36; Shapiro Interview, supra note 12.

62. Whether a clemency applicant is guaranteed counsel varies from state to state. The California Supreme Court guarantees a condemned prisoner representation by an attorney at the clemency stage. In $R e$ Anderson, 69 Cal. 2d 613, 633, 447 P.2d 117, 131, 73 Cal. Rptr. 21, 35 (1968). Some states do not guarantee counsel. E.g., Georgia State Board of Pardons and Paroles, Rule Book 5 (1979). Counsel is guaranteed by statute or administrative rule in some states, e.g., FLA. STAT. 925.035(4) (1979), but the adequacy of appointed representation is disputed, see Wolfgang, Kelly, \& Nolde, supra note 19, at 309 (higher percentage of applicants with privately retained counsel granted clemency than those represented by court-appointed attorneys); Interview with Patsy Morris, supra note 17 (attorney for clemency applicant failed to appear at hearing; "obviously unprepared" at subsequently scheduled hearing); cf. FLA. STAT. $\$ 925.035(4)$ (1979) (limiting compensation of appointed counsel to $\$ 1000$ ).

63. Georgia classifies information privately revealed to clemency authority as a "state secret." Georgia State Board of Pardons and Paroles, Rule Book 6 (1979). Florida permits, but does not require, confidential information contained in the report of the Parole and Probation Commission to be revealed to the attorney for the applicant. Fla. R. Exec. Clemency 7(B)(b). However, there is no explicit requirement that confidential information obtained by the governor or cabinet from other sources must be revealed. Id. 7(E); Shapiro Interview, supra note 12.

64. Petition for Writ of Certiorari at 11 n.2, Sullivan v. Askew, 348 So. 2d 312 (Fla.), cert denied, 434 U.S. 878 (1977) (rules officially construed as barring inmate's presence); Interview with Craig Barnard, Attorney for Florida clemency applicants, in West Palm Beach, Fla. (July 3, 1980) (request for appearance by inmate denied) (notes on file with Yale Law Journal); Lee Interview, supra note 16 (no appearance by inmates permitted in Georgia as matter of practice).

65. Bishop Hearing, supra note 7, at 24 (less than 24 hour notice).

66. See, e.g., N.C. GEN. STAT. $\$ \$ 147-21$ to -25 (1974) (no provision for hearing); OHIo REv. CODE ANN. \$§ 2967.03, .07 (Page 1975) (authorizing investigation but no hearing); Interview with David Emil, supra note 13 (New York practice is investigation but no hearing).

67. See notes 5, 19 supra (courts have not favored arguments that constitutional requirements apply at clemency stage). 


\section{Constitutional Protection for the Applicant}

The unique severity of the punishment of death ${ }^{88}$ has important implications for the clemency process. The Supreme Court has surrounded the death penalty with special procedural protections for persons accused or convicted of capital offenses. ${ }^{60}$ Because clemency is functionally integrated with the earlier stages of the process of determining punishment, certain procedural protections that currently exist prior to a clemency application should be enforced when a condemned prisoner seeks clemency.

\section{A. Procedural Protections in Death Penalty Cases}

Although unwilling to hold that capital punishment itself is unconstitutional, ${ }^{70}$ the Supreme Court has applied strict procedural standards to the state's power to use the death penalty. ${ }^{71}$ The dif-

68. The unifying theme of the Supreme Court's recent capital punishment decisions is that death is a punishment different from all others. E.g., Beck v. Alabama, 447 U.S. 625, $637-38$ (1980) (constitutional difference between death and lesser punishments often stated); Lockett v. Ohio, 438 U.S. 586, 605 (1978) (Burger, C.J.) (death profoundly different from all other penalties); Gardner v. Florida, 430 U.S. 349, 357-58 (1977) (plurality opinion) (Stevens, J.) (government taking life of citizen differs dramatically from any other state action); Woodson v. North Carolina, 428 U.S. 280, 305 (1976) (plurality opinion) (Stewart, Powell, \& Stevens, JJ.) (death differs more from life imprisonment than 100-year prison term differs from term of year or two); id, at 323 (Rehnquist, J., dissenting) (death is different because irreversible, ultimate penalty); Furman v. Georgia, 408 U.S. 238, 286-91 (1972) (Brennan, J., concurring) (death penalty uniquely degrading to human dignity); $i d$. at $\mathbf{3 0 6}$ (Stewart, J., concurring) (death different not in degree but in kind); see Evans v. Bennett, 440 U.S. 1301, 1306 (1979) (Rehnquist, Circuit Justice) (irreversibility of death penalty compels granting stay of execution); Furman v. Georgia, 408 U.S. at 358.60 (Marshall, J., concurring) (death penalty excessive and morally unacceptable punishment violating Eighth Amendment).

69. Beck v. Alabama, 447 U.S. 625, 637-38 (1980) (procedures decreasing reliability invalidated because death is different); see Radin, Cruel Punishment and Respect for Persons: Super Due Process for Death, 53 S. CaL. L. REv. 1143 (1980) (examining link between uniqueness of death penalty and procedural requirements). The notion that death penalty cases compel more stringent procedural requirements was articulated by the Supreme Court long before the most recent cases. See Reid v. Covert, 354 U.S. 1, 77 (1957) (Harlan, J., concurring in result) (process due in noncapital case may not suffice in capital case); Griffin v. Illinois, 351 U.S. 12, 21 (1956) (Frankfurter, J., concurring) (capital offenses are sui generis); Powell v. Alabama, 287 U.S. 45, 71 (1932) (due process requires appointment of effective counsel in capital cases). Contra, Williams v. New York, 337 U.S. 24l, 251 (1949) (declining to draw constitutional distinction in procedure when death may be imposed). The Court later limited the procedural holding in Williams to noncapital cases because the constitutional difference in death as a punishment had since been recognized. Gardner v. Florida, 430 U.S. 349, $357^{\circ}$ (1977) (plurality opinion).

70. Gregg v. Georgia, 428 U.S. 153 (1976) (plurality opinion); see Furman v. Georgia, 408 U.S. 238 (1972). See generally note 2 supra (describing evolution of recent capital cases).

71. The Court derives this procedural requirement from two sources. In Furman v. Georgia, 408 U.S. 238 (1972), the Court held that capital punishment, when its imposition is utterly discretionary, is open to random or discriminatory application, and there- 


\section{Glemency}

ference between death and all other punishments, the Court has reasoned," gives rise to a "corresponding difference in the need for reliability in the determination that death is the appropriate punishment in a specific case." 73 Two general procedural values have emerged in the Court's new capital punishment doctrine: the importance of individualized sentencing, and the need to minimize informational errors. ${ }^{74}$

\section{Individualized Sentencing}

Since its decision in Furman $v$. Georgia, ${ }^{75}$ the Supreme Court has reviewed a variety of state statutes that establish procedures for selecting serious criminal offenders for the death penalty. Statutes that left state courts no discretion to show leniency in individual casesthe so-called "mandatory" death penalty laws-were struck down in

fore unconstitutional. The Court thus provided procedural content to the Eighth Amendment and the equal protection clause.

The Court has also relied on the due process clause, the more traditional source of procedural protection. See Gardner v. Florida, 430 U.S. 349, 362 (1977) (plurality opinion). But see id. at 364 (White, J., concurring in judgment) (resting opinion on Eighth Amendment); Furman v. Georgia, 408 U.S. 238, 255.56 (1972) (Douglas, J., concurring) (Eighth Amendment incorporates requirements of due process clause). See generally note 2 supra (outlining procedural requirements in capital cases).

72. Woodson v. North Carolina, 428 U.S. 280 (1976) (plurality opinion).

73. Id. at 305 .

74. These concerns correspond to the instrumental theory of the value of due process, which holds that due process serves to implement the rule of law by minimizing error in the law's application. In contrast, the theory of the intrinsic value of due process is that regardless of the correctness of the result, it is important that a decision be reached through a fair procedure, one that engenders a feeling of just treatment. See Joint Anti-Fascist Refugee Comm. v. McGrath, 341 U.S. 123, 162-72 (1951) (Frankfurter, $J$., concurring) (important for popular government to generate feeling that justice has been done); id. at 179 (Douglas, J., concurring) (adherence to procedural safeguards best assurance of equal justice under law); L. Tribe, American Constitutional Law 501.06 (1978) (describing instrumental and intrinsic value theories); Michelman, Formal and Associational Aims in Procedural Due Process, in Nomos XVIII, DUE Process 126, 126-29 (J. Pennock \& J. Chapman eds. 1977) (Yearbook of American Society for Political and Legal Philosophy) (distinguishing between legal and social functions of due process). This feeling of just treatment is especially important when what is at stake represents the most profound expression of governmental authority: the power over life and death.

From the point of view of society, the action of the sovereign in taking the life of one of its citizens ... differs dramatically from any other legitimate state action. It is of vital importance to the defendant and to the community that any decision to impose the death sentence be, and appear to be, based on reason rather than caprice or emotion.

Gardner v. Florida, 430 U.S. 349, 357-58 (1977) (plurality opinion) (emphasis added).

The validity and moral authority of a conclusion largely depend on the mode by which it is reached. Joint Anti-Fascist Refugee Comm. v. McGrath, 341 U.S. at 171. When the procedural protections that routinely safeguard decisions of far less moment are absent, the appearance of justice-indeed, the essence of justice-is denied.

75. 408 U.S. 238 (1972). 
1976.76 The Court has approved death penalty laws that sever the determination of guilt from the fixing of sentence. ${ }^{77}$ Subsequently, in Lockett v. Ohio, ${ }^{78}$ the Court disapproved a statute that restricted consideration of mitigating factors to a limited number of theories. ${ }^{79}$ At sentencing, the Court has held, the offender must be permitted to offer a range of arguments and facts in favor of a penalty less than death. ${ }^{80}$ Thus, only carefully individualized sentencing will meet the majority's requirements. ${ }^{81}$

The post-Furman decisions have, in effect, required the states that employ capital punishment to enhance an offender's opportunities to explain why he should not be selected for the punishment of death. The state capital punishment laws disapproved by the Supreme Court since Furman are those that, like a one-way ratchet, operate to tighten gradually and irreversibly the grip of a death sentence on an offender; the approved procedures, on the other hand, permit an offender to escape the death penalty at a number of points in the process of determining punishment. ${ }^{82}$ Individualized sentencing thus involves a policy that favors the exclusion of offenders from the death penalty.

\section{Minimization of Informational Error}

The Supreme Court also requires procedural protections designed to enhance the accuracy of information used by courts in determining the punishment of persons convicted of capital offenses. Although confidential presentence reports are routinely relied on in noncapital cases, the Court's protections prohibit their use in capital cases because the "risk that some of the information accepted in confidence may be erroneous or may be misinterpreted, by the investigator or

76. Roberts v. Louisiana, 428 U.S. 325 (1976) (plurality opinion); Woodson v. North Carolina, 428 U.S. 280 (1976) (plurality opinion); cf. Beck v. Alabama, 447 U.S. 625, 638-43 (1980) (prohibition against instructing jury on lesser included offenses is unconstitutional in capital case). The Court has reserved for decision the constitutionality of a mandatory death-penalty statute for murder or assault with a deadly weapon committed by a life-term prisoner. Woodson v. North Carolina, 428 U.S. at 292 n.25 (dictum).

77. See note 2 supra (bifurcation feature of death penalty laws approved as constitutional).

78. 438 U.S. 586 (1978).

79. Id. at 607-08; see Ohio Rev. Code ANN. § 2929.04(B) (Page 1975).

80. Lockett v. Ohio, 438 U.S. 586, $604-05$ (1978).

81. Furman v. Georgia, 408 U.S. 238, 313 (White, J., concurring) (capital sentencing scheme must provide meaningful basis for distinguishing few cases in which death penalty is imposed from those in which it is not); see Beck v. Alabama, 447 U.S. 625, 638-43 (1980) (unavailability of lesser included offense instruction gives jury discretion that is unconstitutional without standards); Godfrey v. Georgia, 446 U.S. 420, 428-29 (1980) (plurality opinion) (vagueness of capital statute's definition of aggravating circumstances allows unconstitutional discretion in application).

82. See note 2 supra (describing procedures required for imposition of death sentence). 


\section{Clemency}

by the sentencing judge, is manifest." ${ }^{88}$ Such reports introduce a risk of error unacceptable when life is at stake. The Court has held that sentencing information must be submitted to an offender to permit the "debate between adversaries [which] is often essential to the truthseeking function." 84

\section{B. The Death Penalty Doctrine's Challenge to Executive Clemency Procedures}

Clemency, no less than other decisions in the capital punishment process, involves these two procedural values. The principle of individualized sentencing lies at the heart of both the historical and contemporary models of executive clemency:85 perhaps at no other stage of the capital punishment process is the state's power to exclude offenders from a death sentence more dramatic. Avoiding informational errors is also as important at the end of the process of determining punishment as it is earlier. Indeed, clemency long predates sophisticated judicial sentencing procedures as a method for presenting mitigating information. ${ }^{86}$

Procedural inadequacies in the current system suggest, however, that clemency decisions may be based on seriously incomplete views of a petitioner's case. ${ }^{87}$ If information is inadequate or inaccurate, the clemency decision cannot contribute to rational, individualized punishment, ${ }^{88}$ nor can it be trusted to be free of informational error ${ }^{88}$ The Court's constitutional design for administration of the death pen-

83. Gardner v. Florida, 430 U.S. 349,359 (1977) (plurality opinion).

84. Id. at 360. But see Brown v. Wainwright, 28 Crum. L. Rep. (BNA) 2477, 2478 (Fla. Sup. Ct. Jan. 15, 1981) (exposure of state supreme court justices to material withheld from appellant did not taint required review of death sentence).

85. See pp. 892-93, 895-96 supra (historical and contemporary function of clemency is to tailor punishment to individual).

86. See id. (clemency is opportunity for consideration of mitigating factors); note 17 supra (despite consideration of mitigating circumstances by sentencer, clemency still performs unique function).

87. See pp. 900-01 supra (inadequacies of current clemency procedures). A collection of abuses under current clemency provisions has never been attempted on a systematic basis. Because of the current unaccountability of the decisionmaker, many information abuses are likely to remain hidden.

88. See Lockett v. Ohio, 438 U.S. 586, 604-05 (1978) (Burger, C.J.) (incomplete information does not satisfy constitutional requirement for individualized sentencing).

89. Clemency cannot properly function with inaccurate information. Thus Lord ChuterEde, the British Home Secretary who, in 1950, failed to grant clemency to a man later given a posthumous pardon, said, "I did not make a mistake ... . The mistake was that the whole of the facts were not before the court." F. BRESLER, supra note 9, at 224; cf. Townsend v. Burke, 394 U.S. 736, 741 (1948) (sentence based on misinformation cannot stand). For examples of people convicted of capital crimes who were later discovered to have been innocent, see H. BEDAU, supra note 1 , at 494.52, and G. MILLER, INVTrATION to A LYNCHING (1976). 
alty is therefore frustrated at the last stage of the process. ${ }^{00}$

In light of the Supreme Court's death penalty doctrine, such a gap between clemency's ideal function and its actual operation forces a choice upon the states. Conceivably, states might abolish capital clemency. So long as they consider clemency important enough, however, to play its traditional role in their capital punishment system, the states should ensure that the Court's general standards for accuracy are met when the fate of condemned prisoners comes before their clemency authorities for review.

\section{Abolishing Capital Clemency}

The first alternative, abolishing capital clemency, would cure procedural inadequacies at the end of the process of determining punishment by eliminating clemency as a feature of a state's constitutional and statutory law. Abolition of capital clemency might itself, however, entail federal constitutional problems. The capital clemency power has always played an unquestionably important role in American criminal law enforcement, ${ }^{91}$ and each state whose capital punishment law has been approved by the Supreme Court since Furman $v$. Georgia $a^{92}$ has a clemency provision. ${ }^{93}$ Given the importance the Court has attached to mechanisms for excluding individuals from the punishment of death, ${ }^{94}$ a death penalty law that lacks a clemency provision might violate the Eighth and the Fourteenth Amendments. ${ }^{95}$ Earlier stages of the punishment-determination process could serve some of

90. The practical results can be easily demonstrated. The Court ruled in Gardner v. Florida, 430 U.S. 349 (1977) (plurality opinion), that a judge could not rely on a confidential presentence report in deciding upon a death sentence. See pp. 904-05 supra. Yet unless the protection of the due process clause is extended to the clemency stage, the same information deemed too unreliable for the judge can be presented to the clemency authority and serve as the basis for its life-or-death decision. The constitutional value recognized by the Court in Gardner would be subverted.

91. See pp. $895-98$ supra (clemency is integral part of criminal justice system).

92. 408 U.S. 238 (1972).

93. Jurek v. Texas, 428 U.S. 262, 274 (1976) (plurality opinion) (executive clemency approved as part of process of exempting persons from death sentence); Proffitt v. Florida, 428 U.S. 242, 254 (1976) (plurality opinion) (same); Gregg v. Georgia, 428 U.S. 153, 199 (1976) (plurality opinion) (same); see FLA. Consr. art. IV, § 8(a) (governor may commute death sentence with approval of three cabinet members); GA. CoNsT. \$ 2-2001 (Board of Pardons and Paroles may commute death sentence unless governor refuses to reprieve); TEx. ConsT. art. IV, $\$ 11$ (governor may commute death sentence upon advice of Board of Pardons and Parole).

94. See pp. 903-04 supra (statutes must afford opportunity to be excluded from death sentence).

95. Gregg v. Georgia, 428 U.S. 153, 199 n.50 (1976) (plurality opinion) (dictum) (capital punishment system without clemency provision "would be totally alien to our notions of criminal justice"). 


\section{Glemency}

the functions of clemency. ${ }^{96}$ Yet the commitment of final reviewing power to political authorities could hardly be duplicated in a system lacking a clemency feature without a radical change in the character of the earlier, judicial proceedings.

\section{Complying with Procedural Standards at the Clemency Stage}

If, instead of abolishing capital clemency, the states retain the clemency power within the capital punishment process, their clemency authorities should conform to the Supreme Court's procedural standards for administering the death penalty. The federal courts should enforce the requirement that states implement procedures to ensure that the clemency decisionmaker receives complete and accurate information..$^{87}$

Unlike abolition of capital clemency, judicial supervision of clemency procedures required by the Supreme Court's death penalty doctrine would leave intact the traditional multiple-stage capital punishment process. In order to protect the assertedly political nature of clemency, the federal courts should impose procedural requirements on executive authorities in ways that leave the substantive decisionmaking power of those authorities undisturbed. ${ }^{98}$ The courts would

96. But see note 17 supra (clemency serves unique function).

97. Although procedural protection can assure that information comes before the clemency authority, that body still retains the power to make a decision disregarding the facts. A random or otherwise irrational choice is therefore possible. But see note 19 supra (random choice may be unconstitutionally arbitrary). However, the gravity of the question, accountability within the political process, and other institutional constraints may steer the choice toward the rational, in which information is valuable, rather than the purely random, in which information is irrelevant. See Roberts v. Louisiana, 428 U.S. 325, 350 (1976) (White, J., dissenting) ("The country's experience with the commutation power does not suggest that it is a senseless lottery, [or] that it operates in an arbitrary or discriminatory manner ....") Contra, C. Black, Capital Punishment: The INEVITABILITY OF CAPRICE AND MISTAKe 74 (1974) (decision on clemency is final irrational choice in series of such choices); Wolfgang, Kelly, \& Noble, supra note 19, at 305-11 (offenders who are black, foreign-born, or represented by court-appointed counsel less likely to be granted clemency).

98. This distinction is currently made in the administrative law context. See Citizens to Preserve Overton Park, Inc. v. Volpe, 401 U.S. 402, 416-17 (1971) (court may review executive decision for procedural compliance but may not substitute its judgment); United States ex rel. Accardi v. Shaughnessy, 347 U.S. 260, 266-67 (1954) (Attorney General must adhere to procedural requirements notwithstanding discretion). The task, however, must be handled sensitively to keep procedure from swallowing substance. $C f$. Underwood, The Thumb on the Scales of Justice: Burdens of Persuasion in Criminal Cases, 86 YALE L.J. 1299, 1318 (1977) (procedural change may mask substantive change). Compare Breyer, Vermont Yankee and the Courts' Role in the Nuclear Energy Controversy, 91 HARv. L. REv. 1833, 1835 (1978) (imposition of more stringent procedural requirements favors the status quo) with Stewart, Vermont Yankee and the Evolution of Administrative Procedure, 91 HARv. L. REv. 1805, 1811 n.26 (1978) (courts must look to principles, not predictions of impact, in determining standard of review). 
not guarantee a prisoner a right to clemency; a prisoner instead would have a right to procedural protections that ensure care and accuracy in the clemency decision. ${ }^{98}$ By enforcing compliance with current death penalty doctrine at the clemency stage, the courts would in fact merely enforce the traditional expectation of care and accuracy in the administration of clemency.

\section{Specific Procedural Requirements.}

The Supreme Court's standards for individualized sentencing and minimization of informational error require several simple procedural protections. ${ }^{100}$ Because the clemency decision involves a wide range of factors, issues raised in particular cases may make additional procedures essential in order to meet the constitutional standard. Enforcing those procedural requirements would enhance the ability of the clemency authority to function as the final and political stage of review in capital cases.

The clemency authority should permit an applicant, his supporters, the state authorities, and the public at large to comment upon a clemency petition. ${ }^{101}$ Because of the breadth of factors involved in a clemency application, participants could urge granting or denying clemency for any reason. To protect the accuracy of the process, any person should also be permitted to comment upon other submissions to the clemency authority, and all comments should be public, so that factual errors or distortions might be challenged. ${ }^{102}$ Such a proceeding would enhance the public character of the clemency deci-

99. A constitutional interest in the character of the procedure is analytically distinct from a right to a particular result. Gardner v. Florida, 430 U.S. 349, 358 (1977) (plurality opinion); see Joint Anti-Fascist Refugee Comm. v. McGrath, 341 U.S. 123, 185 (1951) (Jackson, J., concurring) (even if there is no legal right to government job, one cannot be adjudged ineligible without due process); L. TRIBE, supra note 74, at 503 (procedural rights distinct from right to outcome).

100. The procedures set forth in this Note are intended as a guiding first step. As more experience is acquired under these rules, adjustments may be made that will further enhance the fairness and accuracy of the proceedings.

101. This also requires adequate notice to prepare and present such comments. See Joint Anti-Fascist Refugee Comm. v. McGrath, 341 U.S. 123, 171-72 (1951) (Frankfurter, J., concurring); Mullane v. Central Hanover Bank \& Trust Co., 339 U.S. 306, 314 (1950).

102. See Gardner v. Florida, 430 U.S. 349 (1977) (plurality opinion) (prohibiting trial court's reliance on confidential information in determining death sentence). Testimony under oath and the opportunity for cross-examination of adverse witnesses would provide additional protection against inaccuracy. See MCCoRMICK's HANDBOoK OF THE LAW or Evidence $\$ 245$, at $581-83$ (2d ed. 1972). The Supreme Court has limited this right for prisoners in liberty-interest cases in order to protect confidential informers. Wolff $v$. McDonnell, 418 U.S. 539, 566 (1974); Morrissey v. Brewer, 408 U.S. 471, 487 (1972). However, the importance of reliability in death cases would clearly outweigh any advantages of such evidence. See Gardner v. Florida, 430 U.S. 349, 359 (1977) (plurality opinion). 
sion in a manner consistent with the historical and contemporary models of clemency. ${ }^{103}$

In practice, this hearing would be dominated by the clemency applicant and state authorities. To ensure its effectiveness, the state should provide adequate resources to an indigent applicant ${ }^{104}$ for the preparation of his presentation. ${ }^{105}$ At a minimum, the state should guarantee the assistance of counsel..$^{106}$ Because certain considerations -typically, evidence of the applicant's remorse-cannot adequately be conveyed on paper, all applicants should be entitled to a personal ap-

103. Procedural protection would also enhance the inherent fairness of the proceeding. See note 74 supra (discussing intrinsic value theory of procedure).

104. Indigency is a likely characteristic of a death row inmate. See Bowers \& Pierce, Arbitrariness and Discrimination under Post-Furman Capital Statutes, 26 Crim. \& DelinQUENCY 563, 580.85 (1980) (numerous studies show that offenders most likely to receive death sentence belong to racial minority or lower class); Riedel, Discrimination in the Imposition of the Death Penalty: A Comparison of Characteristics of Offenders Sentenced Pre-Furman and Post-Furman, 49 TEMPLE L.Q. 261, 284-85 (1976) (death row inmates disproportionately poor, black, uneducated, unskilled); DiSalle, supra note 16, at 72 (death row inmates are without funds for adequate defense).

105. The Court should apply to clemency its reasoning in Griffin v. Illinois, 351 U.S. 12 (1952):

It is true that a State is not required by the Federal Constitution to provide appellate courts or a right to appellate review at all. But that is not to say that a State that does grant appellate review can do so in a way that discriminates against some convicted defendants on account of their poverty.

Id. at 18 (citations omitted); see Mayer v. City of Chicago, 404 U.S. 189, 196-97 (1971) ("flat prohibition against pricing indigent defendants out of as effective an appeal as would be available to others who pay their own way"); Burns v. Ohio, 360 U.S. 252, 258 (1959) (indigents must have same opportunity to invoke discretion of courts as those who can afford costs).

In fact, the theoretical basis of Griffin is even more compelling for capital clemency. First, there is a constitutional difference in death as a punishment. See note 68 supra. In addition, the integral role played by clemency in the capital punishment system, see notes 10, 30-40, 95 supra, might make the elimination of the opportunity for clemency constitutionally fatal. See note 95 supra. Analytically, then, clemency may be closer to an appeal of right than to the discretionary appeal protected in Griffin.

106. The Supreme Court has long recognized that the right to be heard would be of little avail if it did not include the right to counsel. Powell v. Alabama, 287 U.S. 45, 68.69 (1932). In a post-conviction setting, the Court requires appointment of counsel for indigents when information obtained after conviction may affect the sentence. See Mempa v. Rhay, 389 U.S. 128, 134-37 (1967) (attorney required whether proceeding labelled probation revocation or deferred sentencing); Specht v. Patterson, 386 U.S. 605, 608 (1967) (attorney required for additional determination to be made for sentencing under sex-offender's statute); cf. note 17 supra (new information may be heard by clemency authority in making its determination). Counsel is also provided for an appeal as of right. Douglas v. California, 372 U.S. 353, 355 (1963). Indeed, the guiding hand of counsel, Powell v. Alabama, 287 U.S. at 69 , is a requirement of due process at every critical stage of criminal proceedings by the state against an individual. See Estelle v. Smith, 49 U.S.L.W. 4490, 4494 (U.S. May 19, 1981); Coleman v. Alabama, 399 U.S. 1, 7 (1970) (plurality opinion); United States v. Wade, 338 U.S. 218, 227 (1949). The clemency decision is such a critical stage, and thus the appointment of counsel is necessary. See p. 905 supra (power of state most dramatic at clemency stage); notes 10, 30-40, 95 supra (clemency integral part of process of determining punishment). 
pearance before the decisionmaker. ${ }^{107}$ The value of individualized sentencing established by the death penalty cases would be ill served if, at the end of the capital punishment process, the clemency authority had a less vivid impression of the offender's character than that acquired by the prosecutor, the jury, and the judges in the case.

Particular cases may raise issues for the clemency decisionmaker that would require further formal proceedings if the state is to meet the standards of individualized sentencing and minimizing informational error. The assistance of psychiatric personnel, criminologists, or other specialists might be required to help petitioner and his counsel raise and define issues that otherwise would not be presented to the clemency authority. ${ }^{108}$ The application might raise questions that cannot be resolved without the hearing of oral evidence by the clemency decisionmaker, or designated agents, involving exercise of subpoena powers and oath-taking. ${ }^{108}$ The specific requirements in each case would, however, depend on the nature of the issues raised in the course of the clemency process.

Although judicial review of the adequacy of the clemency process, if challenged by the clemency applicant, should be informed by the procedural standards of the death penalty cases, the clemency decision could remain substantively unreviewable. A judicial examination of

107. See Shapiro Interview, supra note 12 (personal appearance necessary to determine appropriateness of punishment for individual); cf. Lockett v. Ohio, 438 U.S. 586, 604 (1978) (Burger, C.J.) (prohibiting exclusion from sentencing hearing of any relevant mitigating evidence); Green v. United States, 365 U.S. 301, 304 (1961) (right of allocution is personal to accused, not merely counsel); FED. R. CRIM. P. 32(a)(1) (defendant shall have right to personal statement before sentencing).

Of course, this would in no way infringe upon the applicant's right not to appear, whether to make a more favorable impression or for any other reason. See Estelle v. Smith, 49 U.S.L.W. 4490, 4492 (U.S. May 19, 1981) (rejecting contention that constitutional protection against self-incrimination limited to preconviction); In re Gault, 387 U.S. 1, 49 (1967) (Fifth Amendment protection turns on nature of admission rather than on nature of proceeding).

108. See Shapiro Interview, supra note 12 (investigative, diagnostic, and other expert assistance necessary fully to develop issues presented in clemency application); Lee Interview, supra note 16 (state consults experts when necessary in investigating clemency applications).

109. An oral hearing would also increase the value of the information presented to the clemency authority by permitting both the decisionmaker and the parties to focus on factors of interest to the decisionmaker. See Goldberg v. Kelly, 397 U.S. 254, 269, 270 (1970); Stewart, supra note 98, at 1813; cf. Shapiro Interview, supra note 12 (oral testimony of witnesses such as psychiatrists, prison chaplain, and family of applicant more effective than written affidavits).

Courts have debated, in the administrative law context, whether oral procedures should be required in order to probe and augment the documentary record. Compare International Harvester Co. v. Ruckleshaus, 478 F.2d 615, 649 (D.C. Cir. 1973) (granting right to cross-examination) with Ethyl Corp. v. EPA, 541 F.2d 1, $48-53$ (D.C. Cir.), cert. denied, 426 U.S. 941 (1976) (denying right to cross-examination). 


\section{Clemency}

the clemency authority's decision to deny or grant the applicant certain procedures should be conducted in a way that would not influence the clemency authority's decision on the merits of the petition, or compromise the independence of the clemency decisionmaking process.

\section{Conclusion}

The Supreme Court has set high procedural standards to reduce the risk of informational error and provide individualized sentencing in death penalty cases. Yet the effect of procedural protection early in the capital punishment process is negated when the lack of procedural protection reintroduces those risks at the clemency stage. Certain due process guarantees should be extended to capital clemency to protect the constitutional values expressed by the Court when life is at stake. 